\title{
Mountain ridge and sea: Geographic-barrier effects on genetic diversity and differentiation of the Hong Kong newt (Paramesotriton hongkongensis) revealed by AFLP
}

\author{
Yi-Xin Zhang ${ }^{1, *, \#, ~ C h e n g-Z h o n g ~ H e ~}{ }^{2, \#}$, David Dudgeon ${ }^{3}$, Zhi-Yi Zhang $^{4}$ \& \\ Gui-Ming Wang ${ }^{5}$
}

1) Department of Biology, Texas State University at San Marcos, San Marcos, TX 78666, USA ( ${ }^{*}$ corresponding author's e-mail: yz11@txstate.edu)

2) College of Resources, Southwest Forestry University, Kunming 650224, China

3) School of Biological Sciences, The University of Hong Kong, Hong Kong SAR, China

4) Beijing Forestry University, Beijing 100083, China

5) Department of Wildlife, Fisheries and Aquaculture, Mississippi State University, Mississippi State, Mississippi 39762, USA

Received 11 Aug. 2010, revised version received 24 Nov. 2010, accepted 12 Dec. 2010

Zhang, Y. X., He. C. Z., Dudgeon, D., Zhang, Z. Y. \& Wang, G. M. 2011: Mountain ridge and sea: Geographic-barrier effects on genetic diversity and differentiation of the Hong Kong newt (Paramesotriton hongkongensis) revealed by AFLP. - Ann. Zool. Fennici 48: 119-127.

The Hong Kong newt (Paramesotriton hongkongensis) has a restricted distribution in Hong Kong and its adjacent coastal area in China. We employed amplified fragment length polymorphism (AFLP) DNA markers to examine the genetic diversity and differentiation of $P$. hongkongensis populations (101 individuals) from three streams. Two mainland populations are separated by Tai Mo Shan, the highest peak in Hong Kong. On Hong Kong Island, there is only one population. We investigated whether the marine barrier would affect the population genetic structure and diversification of Hong Kong newts more than an upland peak barrier. With seven selected primer combinations, 476 AFLP markers with 102 polymorphic loci indicated that newt populations exhibited considerable genetic differentiation. Our results indicate that the two mainland populations, separated by the mountain ridge, were genetically more distant from each other than from the island population separated by the sea barrier that was created about 6000 years ago. The terrestrial biogeographic barrier appears to be crucial in influencing genetic divergence of Hong Kong newt populations.

\section{Introduction}

Amphibian populations are in decline worldwide due to a complex of local, regional, and global causes (Lips et al. 2005, Storfer et al. 2009). Habitat fragmentation and loss are among the leading causes of amphibian population decline and extinction (Blaustein et al. 1994). The genetic consequences of habitat fragmentation are an important component of population extinction risk assessment for threatened and endangered species. Isolated small populations in fragmented habitats may undergo genetic drift and inbreeding, resulting in a decrease of allelic

\footnotetext{
\# These authors contributed equally to this work.
} 
heterozygosity and loss of rare alleles, and this loss of genetic diversity will increase the extinction risk of small populations (Frankham 2005). Consequently, the estimation of genetic diversity is critical to management and conservation initiatives of concerned and threatened species and populations (Hughes et al. 2009).

The Hong Kong newt, Paramesotriton hongkongensis (Myers \& Leviton 1962) is endemic to Hong Kong and the coastal Guangdong Province, China (Miller 2004), within the northern fringes of the Tropic of Cancer. As the only member of the largely non-tropical order Caudata (tailed amphibians) among the 23 amphibian species found in Hong Kong, Paramesotriton hongkongensis is one of the very few Old-World tropical tailed amphibians. Formerly, the Hong Kong newt was treated as a subspecies of $P$. chinensis (Fei 1999), but its rather distinct physical appearance (larger, and more robust) supports its classification into an independent species (Myers \& Leviton 1962). Anthropogenic disturbances, such as habitat alteration, stream channelization, water pollution, and pet-trade collection led to the designation of $P$. hongkongensis as a protected species by the Agriculture, Fisheries and Conservation Department of the Hong Kong Special Administrative Region (SAR), China. The newt is categorized as globally Near Threatened on the IUCN Red List of endangered species (IUCN Red List 2010), and might be listed as Threatened in the near future. Thus, conservation and ecosystem management plans for maintaining existing populations of $P$. hongkongensis are needed to prevent further decline. However, knowledge about the ecology and population biology of $P$. hongkongensis is highly limited, because of no such studies of the genus Paramesotriton in Asia. Moreover, nothing is known about the genetic diversity and gene flow among $P$. hongkongensis populations inhabiting habitats with different landscape features, such as in a mainland or on islands.

Landscape genetics integrates specific landscape features with population genetics for understanding genetic processes, such as gene flow and genetic drift to shape genetic variation and genetic connectivity, which can provide insights into ecological and evolutionary processes (Manel et al. 2003). Landscape features, such as islands and mountains, can influence dispersal and gene flow among populations (Holderegger \& Wagner 2008). Using molecular markers to identify special barriers to dispersal and gene flow, quantify genetic diversity, and locate genetic discontinuity patterns of populations between contemporary and historic landscapes is a key theme of landscape genetics, because of their high information content (Storfer et al. 2007). A number of molecular markers have been recently developed and their applications in conservation genetics have been remarkably productive and successful (DeSalle \& Amato 2004). Amplified fragment length polymorphism (AFLP) DNA markers are a popular tool of genetic analysis for evolutionary genetics and conservation ecology because of its high information content, reliability, polymorphism, and wide genomic coverage (Vos et al. 1995, Bensch \& Akesson 2005, Meudt \& Clarke 2007, Storfer et al. 2009), in which AFLPs have been more frequently used in plants than animals (Storfer et al. 2010). Additionally, restriction fragments can be visualized by PCR without the knowledge of nucleotide sequence (Ajmone-Marsan et al. 1997, Mock et al. 2002). In this study, using AFLP markers, we evaluated genetic diversity and differentiation among three populations of $P$. hongkongensis in Hong Kong, two on the mainland and one on an island. Our main objective was to provide baseline information on genetic diversity and population genetic structure of $P$. hongkongensis for the conservation and protection of this species. We predicted that geographic barriers relating to mountain ridges and islands would play an important role in generating population genetic diversification. We speculated that the effects of a marine barrier between island and mainland populations on the population genetic structure of the Hong Kong newts is more important than the effects of an upland barrier between mainland populations.

\section{Material and methods}

Paramesotriton hongkongensis is restrictively distributed in several isolated locations on the mainland portion of Hong Kong SAR, as well as 
Fig. 1. Locations of the three sampling streams in Hong Kong, China. PNS: Pak Ngau Shek Stream; TSS: Tai Shing Stream; and TTT: Tai Tam Tuk Stream. Tai Mo Shan is the highest mountain in Hong Kong (958 $\mathrm{m}$ a.s.I.).

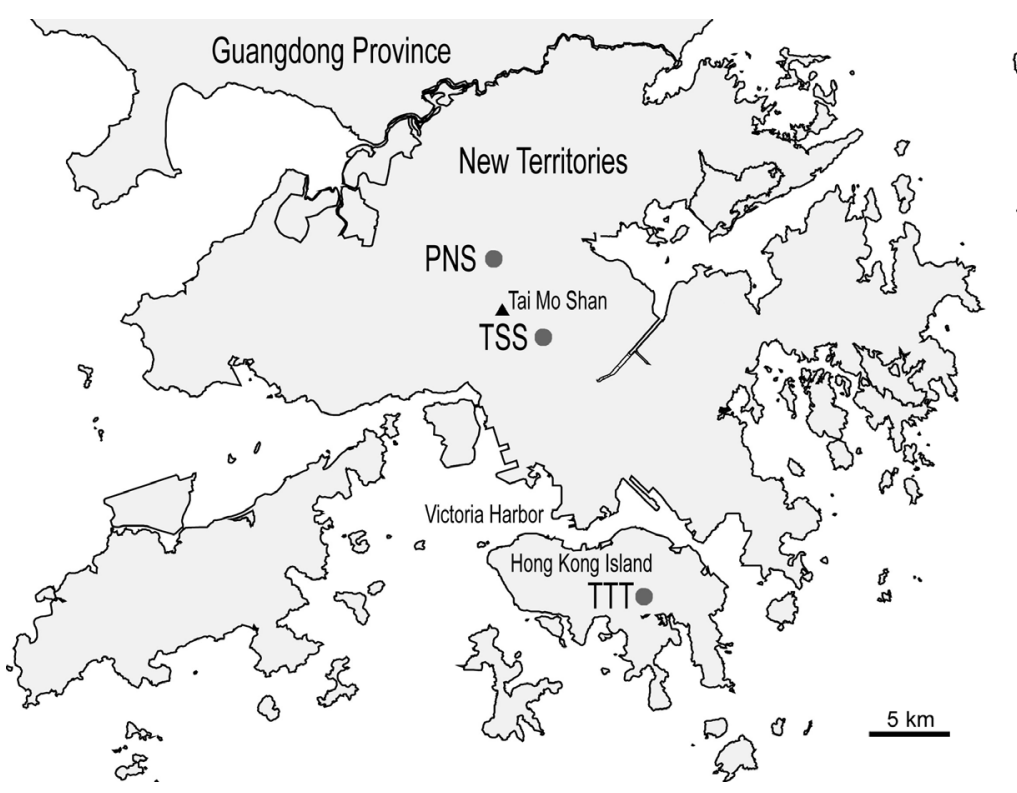

on Hong Kong Island (Karsen et al. 1998, Lau \& Dudgeon 1999). The mainland New Territories and Hong Kong Island are separated by Victoria Harbor, part of the South China Sea (Fig. 1). The newts occur in pools of stony hillstreams with cobbles, boulders and riparian vegetation; they are predators that feed on larval invertebrates, shrimps, snails, fishes and tadpoles (Karsen et al. 1998, Dudgeon \& Corlett 2004, Zhang, personal observation). The Hong Kong Newts were collected from breeding sites in streams on the mainland and Hong Kong Island. Pak Ngau Shek Stream (PNS, UTM grid reference: 50Q KK036844) and Tai Shing Stream (TSS, UTM: 50Q KK065796) were located on the mainland New Territories. These streams were separated by Tai Mo Shan, a rugged peak that is the highest point (958 $\mathrm{m}$ a.s.1.) in Hong Kong. TSS is on the southeastern slope of Tai Mo Shan, while PNS is on the northern slope. Although the Hong Kong newt occurs on both the east and the west sides of Tai Mo Shan, only one population was found on the east side of Tai Mo Shan, which was located in TSS. The samples of Hong Kong newts from PNS and TSS were collected at $80 \mathrm{~m}$ a.s.1. and $200 \mathrm{~m}$ a.s.l., respectively. Those two populations were not connected due to the rugged high peak of Tai Mo Shan. The only population of Hong Kong newts distributed on
Hong Kong Island was in the Tai Tam Tuk Stream (TTT, UTM: 50Q KK123638) at $210 \mathrm{~m}$ a.s.l. (Lau \& Dudgeon 1999).

\section{Sample collection}

A total of 101 P. hongkongensis individuals were live captured using a hand net from the three study sites (34 in PNS, 30 in TSS, and 37 in TTT) in November 2005, which was the early phase of the breeding period when adults congregated in pools. The tail tip about $1 \mathrm{~cm}$ long was non-lethally clipped from each captured individual, and the newts were immediately released to the streams. Tail tissue samples were placed individually in $5.0 \mathrm{ml}$ plastic sampling tubes stored in liquid nitrogen and then frozen at $-80{ }^{\circ} \mathrm{C}$ until DNA extraction. Our capture and handling procedures were approved by the Agriculture, Fisheries and Conservation Department of Hong Kong Special Administration Region.

\section{DNA extraction}

Total genomic DNA was extracted from tail-tip tissue samples using the Aljanabi and Martinez (1997) method, modified in Wang et al. (2001). 
The tissue samples were ground into powder in liquid nitrogen in a $1.5 \mathrm{ml}$ centrifuge tube. $400 \mu 1$ extraction buffer $(0.4 \mathrm{M} \mathrm{NaCl}, 10 \mathrm{mM}$ Tris- $\mathrm{HCl} \mathrm{pH}$ 8.0, 2 mM EDTA pH 8.0, 2\% SDS [w/v], $20 \mu \mathrm{g} \mathrm{m}^{-1}$ RNAse) and $20 \mu 1$ proteinase$\mathrm{K}\left(400 \mu \mathrm{g} \mathrm{ml}^{-1}\right.$ final concentration) were added and tubes were incubated at $60-65^{\circ} \mathrm{C}$ for $1 \mathrm{~h}$ whereupon $300 \mu 1$ of $6 \mathrm{M} \mathrm{NaCl}$ was added to each sample. Samples were vortexed for $30 \mathrm{~s}$ at the maximum speed and centrifuged for $30 \mathrm{~min}$ at $10000 \mathrm{~g}$. DNA was precipitated with isopropanol, rinsed with $70 \%$ ethanol, dried in air, and then resuspended in $100 \mu \mathrm{l}$ of TE buffer $(10 \mathrm{mM}$ Tris, $1 \mathrm{mM}$ EDTA, pH 8.0). Five tubes without tissue samples were treated in the same way as described above in order to check sample contamination. No DNA bands appeared on the agarose gels for these control samples. DNA quality and concentration were evaluated on a $1 \%$ agarose gel in comparison with standard lambda DNA. The DNA samples were stored at $-20{ }^{\circ} \mathrm{C}$.

\section{AFLP procedure}

The AFLP analysis was carried out following the procedure described by Vos et al. (1995) and Ajmone-Marsan et al. (1997). Genomic DNA was digested with $\mathrm{TaqI}$ at $65^{\circ} \mathrm{C}$ for $1 \mathrm{~h}$ and then with EcoRI at $37^{\circ} \mathrm{C}$ for $1 \mathrm{~h}$. Ligation was carried out at $37^{\circ} \mathrm{C}$ for $4 \mathrm{~h}$. Pre-amplification started with an initial 2-min extension step at $72{ }^{\circ} \mathrm{C}$ for the complete adapter ligation (Riberon et al. 2004). All PCR amplifications were performed using a GeneAmp ${ }^{\circledR}$ PCR System 9700 (Perkin Elmer Corp., Norwalk, CT, USA). PCR products were separated by electrophoresis on a $6 \%$ denaturing polyacrylamide gel at $90 \mathrm{~W}$ for $2.5 \mathrm{~h}$ using the SequiGen $38 \times 50 \mathrm{~cm}$ gel apparatus (BioRad Laboratories Inc., Hercules, CA, USA). AFLP patterns were then visualized by silver staining (Merril et al. 1981, Bassam et al. 1991). In order to reduce the effect of erroneous genotypes on the analysis of molecular data sets through quality control (Bonin et al. 2004, Pompanon et al. 2005), 25 samples were randomly chosen for each of 16 candidate primer combinations to be amplified for three times following the above protocol. Among the 16 candidate primer com- binations, 7 primer combinations showed stable fingerprintings among 3 replicates. We selected these 7 primer combinations with consistent DNA fingerprinting for further analysis of all the 101 samples of Hong Kong Newts.

\section{Data analysis}

The AFLP markers were manually scored as present (1) or absent (0) in each newt sample and each primer combination. The binary matrix of polymorphic bands was analyzed using the program POPGENE ver. 1.32 (Yeh et al. 1997) to calculate the observed number of alleles $\left(A_{\mathrm{o}}\right)$, effective number of alleles $\left(A_{\mathrm{e}}\right)$, Nei's (1973) gene diversity $(H)$, Shannon's information index $(I)$, total genetic diversity $\left(H_{\text {tot }}\right)$, genetic diversity within populations $\left(H_{\mathrm{S}}\right)$, the coefficient of genetic differentiation among populations $\left[G_{\mathrm{ST}}\right.$ $\left.=\left(H_{\text {tot }}-H_{\mathrm{S}}\right) / H_{\text {tot }}\right]$, and gene flow $\left[N_{\mathrm{m}}=0.25(1-\right.$ $\left.\left.G_{\mathrm{ST}}\right) / G_{\mathrm{ST}}\right]$ (McDermott \& Mcdonald 1993). We carried out an analysis of molecular variance (AMOVA) to partition total genetic variability into the within- and between-population components and calculated Nei's genetic distances between populations, using program GENALEX 6.1 (Peakall \& Smouse 2006). AMOVA used the $\Phi_{\mathrm{PT}}$ to measure the relative genetic variance among the three populations (TSS, PNS, and TTT) relative to the total genetic variance and used the permutation of 1000 times to test for the significance of $\Phi_{\mathrm{PT}}(p<0.05$; Peakall \& Smouse 2006).

\section{Results}

\section{Genetic variation}

The seven selected primer combinations produced a total of 476 clear fragments/markers for the entire 101 samples. Fragment sizes ranged from approximately 80 to $500 \mathrm{bp}$. The number of markers varied from 45 (E-GAG/T-GAA) to 78 (E-AAG/T-ATC or E-AAG/T-AAA) and averaged 68 markers per primer combination (Table 1). Of the total 476 scored markers, 102 $(21.42 \%)$ were polymorphic. Correspondingly, 
at the species level, the observed number of alleles was 2.0 , the effective number of alleles was 1.24 , Nei's gene diversity was 0.16 , and Shannon's information index was 0.27 for $P$. hongkongensis (Table 2).

\section{Within-population genetic variation}

The percentages of polymorphic loci $(P)$ in individual populations varied from $5.9 \%$ to $17.4 \%$ and averaged $12.4 \%$. The observed number of alleles $\left(A_{\mathrm{o}}\right)$ ranged from 1.28 to 1.92 averaging 1.62 , and the effective number of alleles $\left(A_{\mathrm{e}}\right)$ ranged from 1.09 to 1.25 and averaged 1.24 . Nei's gene diversity $(H)$ averaged 0.16 and ranged from 0.06 to 0.17 , whereas Shannon's information index was 0.27 and ranged from 0.1 to 0.29 . The mainland PNS population had the highest level of genetic diversity whereas the mainland TSS population had the lowest variability (Table 2).

\section{Population genetic structure}

The total genetic diversity $\left(H_{\text {tot }}\right)$ was $0.16 \pm$ 0.03 (mean $\pm \mathrm{SD}$ ), and within-population genetic diversity $\left(H_{\mathrm{S}}\right)$ was $0.12 \pm 0.01$. Moreover, the coefficient of genetic differentiation $\left(G_{\mathrm{ST}}\right)$ was 0.26 , indicating that about $26 \%$ of the total genetic variability could be explained by genetic differences between populations, whereas $74 \%$ was explained by genetic differences among individuals. Between-population variation was significant (AMOVA: $p=0.001$ ) and explained $32 \%$ of total genetic variability, whereas withinpopulation variation explained $68 \%$. The genetic distance between the two mainland populations (PNS and TSS) was twice as long as the distance between either PNS or TSS and the Hong Kong Island population (TTT). The average level of gene flow $\left(N_{\mathrm{m}}\right)$ was estimated to be 1.45 effective migrants per generation among the three $P$. hongkongensis populations. Gene flow between the

Table 1. The number of bands generated by seven primer combinations of amplified fragment length polymorphism (AFLP) markers.

\begin{tabular}{lrcrc}
\hline Primer combination & Marker size & $\begin{array}{c}\text { Number of } \\
\text { markers }\end{array}$ & $\begin{array}{c}\text { Number of } \\
\text { polymorphic } \\
\text { markers }\end{array}$ & $\begin{array}{c}\text { Percentage of } \\
\text { polymorphic } \\
\text { markers }\end{array}$ \\
\hline E-GAG/T-GAA & $100-400 \mathrm{bp}$ & 45 & 9 & 20 \\
E-AAG/T-ATC & $115-410 \mathrm{bp}$ & 78 & 10 & 13 \\
E-AAT/T-GAA & $84-350 \mathrm{bp}$ & 60 & 9 & 15 \\
E-AAG/T-ATT & $100-480 \mathrm{bp}$ & 75 & 20 & 27 \\
E-GAA/T-ATT & $100-500 \mathrm{bp}$ & 72 & 29 & 40 \\
E-AAG/T-AAA & $95-400 \mathrm{bp}$ & 78 & 13 & 17 \\
E-AAG/T-CTC & $80-420 \mathrm{bp}$ & 68 & 12 & 18 \\
Total & & 476 & 102 & \\
\hline
\end{tabular}

Table 2. Genetic variability parameters of the Hong Kong newt populations at three streams (Pak Ngau Shek Stream, Tai Shing Stream, and Tai Tam Tuk Stream) based on amplified fragment length polymorphism (AFLP) markers. $A_{\mathrm{o}}=$ observed number of alleles; $A_{\mathrm{e}}=$ effective number of alleles; $H=$ Nei's gene diversity; $I=$ Shannon's information index.

\begin{tabular}{lcccccc}
\hline Population & Sample size & $\begin{array}{c}\text { Percentage of } \\
\text { polymorphic loci }\end{array}$ & $\begin{array}{c}A_{\mathrm{o}} \\
(\mathrm{mean} \pm \mathrm{SD})\end{array}$ & $\begin{array}{c}A_{\mathrm{e}} \\
(\mathrm{mean} \pm \mathrm{SD})\end{array}$ & $\begin{array}{c}H \\
(\mathrm{mean} \pm \mathrm{SD})\end{array}$ & $\begin{array}{c}I \\
(\mathrm{mean} \pm \mathrm{SD})\end{array}$ \\
\hline Pak Ngau Shek & 34 & 17.44 & $1.92 \pm 0.27$ & $1.25 \pm 0.27$ & $0.17 \pm 0.14$ & $0.29 \pm 0.19$ \\
Tai Tam Tuk & 37 & 13.87 & $1.65 \pm 0.48$ & $1.18 \pm 0.27$ & $0.12 \pm 0.15$ & $0.20 \pm 0.21$ \\
Tai Shing & 30 & 5.88 & $1.28 \pm 0.45$ & $1.09 \pm 0.20$ & $0.06 \pm 0.12$ & $0.10 \pm 0.18$ \\
Mean & 12.40 & 1.62 & 1.24 & 0.16 & 0.27 \\
Total & 101 & 21.43 & $1.99 \pm 0.09$ & $1.24 \pm 0.31$ & $0.16 \pm 0.16$ & $0.27 \pm 0.21$ \\
\hline
\end{tabular}


PNS and TSS populations was 3.87, 1.6 between the PNS and TTT populations, and 1.26 between the TSS and TTT populations.

\section{Discussion}

This study was the first to examine the effect of landscape barriers on the spatial population genetic variation of $P$. hongkongensis, indeed of any Asian salamander. The current genetic distance between the two mainland populations (PNS and TSS) was twice that between either mainland population and newts on Hong Kong island (TTT), which suggests that - contrary to our expectations - the isolation effect of the highest mountain ridge in Hong Kong was significantly stronger than the effects of a salt-water barrier, which was created when sea levels rose 6000 years ago around Hong Kong, and isolated newt populations on the island (Dudgeon \& Corlett, 2004). Evidently, isolation by the mountain ridge may exceed those brought about by 6000 years of separation by an impenetrable marine barrier. Similar isolating effects of mountain ridges on gene flow have been shown in other amphibian species (Lougheed et al. 1999, Tallmon et al. 2000). The TSS and PNS streams were located on the southern and northern slope of Tai Mo Shan, and although distance between these two newt populations was shorter than that between either of the mainland populations and that on Hong Kong Island (Fig. 1), gene flow $\left(N_{\mathrm{m}}\right)$ between the two mainland newt populations was less than half of that between either mainland population and the Hong Kong Island population. Genetic differences between the two newt populations (PNS and TSS) in the New Territories were greater than that between a newt population (PNS or TSS) in the New Territories and the Hong Kong Island newt population

Table 3. Nei's genetic distance between the Hong Kong newt populations at Pak Ngau Shek Stream, Tai Shing Stream, and Tai Tam Tuk Stream.

\begin{tabular}{lcc} 
& Pak Ngau Shek & Tai Tam Tuk \\
\hline Tai Tam Tuk & 0.044 & - \\
Tai Shing & 0.085 & 0.08 \\
\hline
\end{tabular}

(TTT) (Table 3). Since it is unlikely for migration to have occurred across a marine barrier during the past 6000 years, the Hong Kong newt populations between the mainland and the Hong Kong Island must have remained isolated. This implies one of two things: either genetic divergence between the two mainland populations has proceeded more rapidly than between island and mainland populations or, alternatively, that divergence between the two mainland populations had occurred prior to the isolation of island from mainland populations.

The mainland PNS population, which was at the most lowland site, had higher genetic diversity than the other two populations (PNS $>$ TTT $>$ TSS) and this difference appeared to be negatively related to a low-high elevation gradient. We speculate that the genetic diversity among the Hong Kong newt populations might be negatively correlated with elevation, because effective population sizes at high elevation sites are smaller than those at low elevation (author's pers. obs.); and the landscape barrier effect on gene flow can be influential for high elevation populations. Funk et al. (2005) found that mountain ridges and elevational differences (from 733-2652 m a.s.1.) were associated with increased genetic differentiation among sites for the Columbia spotted frog (Rana luteiventris). Since frogs in low-elevation ponds had high genetic variation within populations, it was considered that large low-elevation populations are important sources of immigrants and genetic variation for small populations at high elevations. Because topographic relief significantly limits gene flow, extinction of low-elevation populations may have the unexpected impact of reducing the persistence of mountain populations (Funk et al. 2005). Such altitudinal gradients can shape the spatial distribution of genetic variation of a species. Giordano et al. (2007) showed a significant negative correlation between genetic diversity and altitude in the long-toed salamander (Ambystoma macrodactulym), which parallels the pattern seen in P. hongkongensis. They considered high-altitude uplands to be landscape barriers that restricted gene flow among highaltitude populations relative to low-altitude populations, thus reducing genetic variability among high-altitude populations. 
The population-specific proportion of polymorphic loci in $P$. hongkongensis appears relatively low (5.9\%-17.4\%) in comparison with other animals, such as some warblers with a $25 \%-$ 45\% AFLP-marker polymorphism range (Bensch et al. 2002) and pigs (Sus scrofa) with a $26.4 \%-$ $59.8 \%$ range (Kim et al. 2002). Riberon et al. (2004) postulated that genetic polymorphism of amphibians is low in general, but this is certainly not the case for all amphibians. For instance, the proportion of polymorphic AFLP loci was $54.8 \%$ in the microhylid frog Gastrophryne carolinensis, which ranges widely in the south of the United States, although population genetic differentiation was low (Makowsky et al. 2009). Curtis and Taylor (2004) also showed that the percentage of polymorphic AFLP markers exceeded $50 \%$ in coastal giant salamanders (Dicamptodon tenebrosus), a threatened but widely distributed species in the Pacific Northwest. Our data suggest that genetic polymorphism may be relatively low in endemic salamanders, especially those with restricted distribution ranges, which may be related to a low evolutionary rate in the salamander genome (Wake et al. 1983).

Although genetic polymorphism appeared low, $P$. hongkongensis populations exhibited considerable genetic differentiation with a coefficient of differentiation $\left(G_{\mathrm{ST}}\right)$ of 0.26 , exceeding the value of 0.25 that suggests a high degree of inter-population genetic differentiation (Freeland 2005). AFLP analysis is a powerful tool to assess intra-population genetic diversity and population genetic structure of threatened species (Holderegger \& Wagner 2008), however, few studies have used AFLP markers to evaluate intra- and inter-population genetic variation of salamanders (Makowsky et al. 2009). Riberon et al. (2004) used AFLP to reveal genetic variation between and within populations in two subspecies of Salamandra atra in Europe, although, in that case, low genetic differentiation was ascribed to small sample sizes (1-5). Our results indicate that AFLP markers can certainly detect population genetic structure and differentiation with a sample size of 30-40 individuals. Milá et al. (2010) recently reported a study on the Pyrenean brook newt (Calotriton asper) with extreme dispersal limitation across four drainages in the French Pyrenean, revealing marked population genetic structuring by genome-wide AFLP but not by mtDNA. In this only other AFLP study on newts, a high level of variation in 382 AFLP loci revealed isolation by distance effect, which was consistent with long-term restriction of gene flow among populations of $C$. asper. Milá et al. (2010) concluded that severely underestimated population divergence by using only mtDNA sequence data can lead to erroneous inferences on the true pattern of gene flow of $C$.asper.

Our results suggest that isolation due to geographic landscape barrier or habitat fragmentation, especially in a mountainous region, can result in substantial genetic differentiation between small populations, according to findings by Gibbs (1998). Elsewhere, Curtis and Taylor (2004) showed that forest clear-cutting in British Columbia can contribute to genetic differentiation of Giant salamander populations in clear-cut and forested sites due to smaller population sizes and genetic drift in clear-cut sites.

Our findings on physical barrier effects of an upland ridge and a marine barrier on the genetic divergence of the Hong Kong newt have implications for the conservation and management of amphibians. Given the urgency in the global decline of amphibian diversity (Rovito et al. 2009) and the threat of climate warming on fragmented populations (Sinervo et al. 2010), it is crucial to identify threatened and endangered amphibian species populations with low genetic diversity, restricted gene flow and small population sizes for future protection, because the combination of these three limiting factors can cause even higher vulnerability in geographically restricted endemic amphibian species. To better understand divergence among newt populations and determine those that warrant priority for protection (Bonin et al. 2007), further phylogeographic investigation of the genetic linkages of $P$. hongkongensis populations using mitochondrial DNA markers is needed.

\section{Acknowledgments}

We thank B. Li and X. L. Feng at Beijing Forestry University for their technical assistance in our AFLP analyses, and Lily $\mathrm{Ng}$ for technical support in Hong Kong University. Sampling permission and helpful information were obtained from the Agriculture, Fisheries and Conservation Department, the 
Hong Kong Special Administration Region Government, China. This project was supported financially by the Seed Funding Grant for Basic Research awarded by the University of Hong Kong.

\section{References}

Ajmone-Marsan, P., Valentini, A., Cassandro, M., VecchiottiAntaldi, G., Bertoni, G. \& Kuriper, M. 1997: AFLP ${ }^{\mathrm{TM}}$ markers for DNA fingerprinting in cattle. - Animal Genetics 28: 418-426.

Aljanabi, S. M. \& Martinez, L. 1997: Universal and rapid salt-extraction of high quality genomic DNA for PCRbased techniques. - Nucleic Acids Research 25: 4692 4693.

Bassam, B. J., Caetano-Anolles, G. \& Gresshoff, P. M. 1991: Fast and sensitive silver staining of DNA in polyacrylamide gels. - Analytical Biochemistry 196: 80-83.

Bensch, S., Helbig, A. J., Salomon, M. \& Seibold, I. 2002: Amplified fragment length polymorphism analysis identified hybrids between two subspecies of warblers. Molecular Ecology 11: 473-481.

Bensch, S. \& Akesson, M. 2005: Ten years of AFLP in ecology and evolution: why so few animals? - Molecular Ecology 14: 2899-2914.

Blaustein, A. R., Wake, D. B. \& Sousa, W. P. 1994: Amphibian declines: judging statbility, persistence, and susceptibility of populations to local and global extinctions. - Conservation Biology 8: 60-71.

Bonin, A., Bellemain, E., Eidesen, P. B., Pompanon, F., Brochmann, C. \& Taberlet, P. 2004: How to track and assess genotyping errors in population genetics studies. - Molecular Ecology 13: 3261-3273.

Bonin, A., Nicole, F., Pompanon, F., Miaud, C. \& Taberlet, P. 2007: Population adaptive index: a new method to help measure intraspecific genetic diversity and prioritize populations for conservation. - Conservation Biology 21: 697-708.

Curtis, J. M. R. \& Taylor, E. B. 2004: The genetic structure of coastal giant salamanders (Dicamptodon tenebrosus) in a managed forest. - Biological Conservation 115: $45-54$.

DeSalle, R. \& Amato, G. 2004: The expansion of conservation genetics. - Nature Reviews Genetics 5: 702-712.

Dudgeon, D. \& Corlett, R. T. 2004: The ecology and biodiversity of Hong Kong. - Joint Publishing Company, Hong Kong.

Fei, L. 1999: Atlas of amphibians of China. - Henan Science and Technology Publishing House, Zhengzhou, China.

Frankham, R. 2005: Genetics and extinction. - Biological Conservation 126: 131-140.

Freeland, J. R. 2005: Molecular ecology. - Wiley, New York, USA.

Funk, W. C., Blouin, M. S., Corn, P. S., Maxell, B. A., Pilliod, D. S., Amish, S. \& Allendorf, F. W. 2005: Population structure of Columbia spotted frogs (Rana luteiventris) is strongly affected by the landscape. - Molecular
Ecology 14: 483-496.

Gibbs, J. 1998: Genetic structure of redback salamander Plethodon cinereus populations in continuous and fragmented forests. - Biological Conservation 86: 77-81.

Giordano, A. R., Ridenhour, B. J. \& Storfer, A. 2007: The influence of altitude and topography on genetic structure in the long-toed salamander (Ambystoma macrodactylum). - Molecular Ecology 16: 1625-1637.

Holderegger, R. \& Wagner, H. H. 2008: Landscape genetics. - BioScience 58: 199-207.

Hughes, J. M., Schmidt, D. J. \& Finn, D. S. 2009: Genes in streams: Using DNA to understand the movement of freshwater fauna and their riverine habitat. - BioScience 59: 573-583.

IUCN Red List 2010: IUCN Red List of Threatened Species, version 2010.2. - Available at http://www.iucnredlist. org/apps/redlist/details/59460/0.

Karsen, S. J., Lau, M. W. N. \& Bogadek, A. 1998: Hong Kong amphibians and reptiles, 2nd ed. - Provisional Urban Council, Hong Kong.

Kim, K. S., Yeo, J. S. \& Kim, J. W. 2002: Assessment of genetic diversity of Korean native pig (Sus scrofa) using AFLP markers. - Genes and Genetic Systems 77: 361-368.

Lau, M. W. \& Dudgeon, D. 1999: Composition and distribution of Hong Kong amphibians. - Memoirs of the Hong Kong Natural History Society 22: 1-79.

Lips, K. R., Burrowes, P. A., Mendelson, J. R. III \& ParraOlea, G. 2005: Amphibian declines in Latin America: Widespread population declines, extinctions, and impacts. - Biotropica 37: 163-165.

Lougheed, S. C., Gascon, C., Jones, D. A., Bogart, J. P. \& Boag, P. T. 1999: Ridges and rivers: a test of competing hypotheses of Amazonian diversification using a dartpoison frog (Epipedobates femoralis). - Proceedings of the Royal Society of London B 266: 1829-1835.

Makowsky, R., Chesser, J. \& Rissler, L. J. 2009: A striking leak of genetic diversity across the wide-ranging amphibian Gastrophryne carolinensis (Anura: Microhylidae). - Genetica 135: 169-183.

Manel, S., Schwartz, M. K., Luikart, G. \& Taberlet, P. 2003: Landscape genetics: combining landscape ecology and population genetics. - Trends in Ecology and Evolution 18: 189-197.

McDermott, J. M. \& McDonald, B. A. 1993: Gene flow in plant pathosystems. - Annual Review of Phytopathology 31: 353-373.

Meudt, H. M. \& Clarke, A. C. 2007: Almost forgotten or latest practice? AFLP applications, analyses and advances. - Trends in Plant Science 12: 106-117.

Merril, C. R., Goldman, D., Sedman, S. A. \& Ebert, M. H. 1981: Ultrasensitive stain for proteins in polyacrylamide gels shows regional variation in cerebrospinal fluid proteins. - Science 211: 1437-1438.

Milá, B., Carranza, S., Guillaume, O. \& Clobert, J. 2010: Marked genetic structuring and extreme dispersal limitation in the Pyrenean brook newt Calotriton asper (Amphibia: Salamandridae) revealed by genome-wide AFLP but not mtDNA. - Molecular Ecology 19: 108-120.

Miller, J. J. 2004: Overview of the Salamandridae genus Para- 
mesotriton. - Available at http://www.Livingunderworld. org.

Mock, K. E., Theimer, T. C., Rhodes, O. E., Greeberg, D. L. \& Keim, P. 2002: Genetic variation across the historical range of the wild turkey (Meleagris gallopavo). Molecular Ecology 11: 643-657.

Myers, G. T. \& Leviton, A. E. 1962: The Hong Kong newt described as a new species. - Occasional Papers of the Division of Systematic Biology of Stanford University 10: $1-4$.

Nei, M. 1973: Analysis of gene diversity in subdivided populations. - Proceedings of the National Academy of Sciences USA 70: 3321-3323.

Peakall, R. \& Smouse, P. E. 2006: GENALEX 6: genetic analysis in Excel. Population genetic software for teaching and research. - Molecular Ecology Notes 6: 288-295.

Pompanon, F., Bonin, A., Bellemain, E. \& Taberlet, P. 2005: Genotyping errors: causes, consequences and solutions. - Nature Reviews Genetics 6: 847-859.

Riberon, A., Miaud, C., Guyetant, R. \& Taberlet, P. 2004: Genetic variation in an endemic salamander, Salamandra atra, using amplified fragment length polymorphism. - Molecular Phylogenetics and Evolution 31: 910-914.

Rovito, S. M., Parra-Olea, G., Vásquez-Almazánc, C. R., Papenfussa, T. J. \& Wake, D. B. 2009: Dramatic declines in neotropical salamander populations are an important part of the global amphibian crisis. - Proceedings of the National Academy of Sciences USA 106: 3231-3236.

Sinervo, B., Méndez-de-la-Cruz, F., Miles, D. B., Heulin, B., Bastiaans, E., Villagrán-Santa Cruz, M., Lara-Resendiz, R., Martínez-Méndez, N., Calderón-Espinosa, M. L., Meza-Lázaro, R. N., Gadsden, H., Avila, L. J., Morando, M., De la Riva, I. J., Victoriano Sepulveda, P., Rocha, C.
F., Ibargüengoytía, N., Aguilar Puntriano, C., Massot, M., Lepetz, V., Oksanen, T. A., Chapple, D. G., Bauer, A. M., Branch, W. R., Clobert, J., Sites, J. W. Jr. 2010: Erosion of lizard diversity by climate change and altered thermal niches. - Science 328: 894-899.

Storfer, A., Murphy, M. A., Evans, J. S., Goldberg, C. S., Robinson, S., Spear, S. F., Dezzani, R., Demelle, E., Vierling, L. \& Waits, L. P. 2007: Putting the landscape in landscape genetics. - Heredity 98: 128-142.

Storfer, A., Eastman, J. M. \& Spear, S. F. 2009: Modern molecular methods for amphibian conservation. - BioScience 59: 559-571.

Storfer, A., Murphy, M. A., Spear, S. F., Holderegger, R. \& Waits, L. P. 2010: Landscape genetics: where are we now? - Molecular Ecology 19: 3496-3514.

Tallmon, D. A., Funk, W. C., Dunlap, W. W. \& Allendorf, F. W. 2000: Genetic differentiation among long-toed salamander (Ambystoma macrodactylum) populations. - Copeia 2000: 27-35.

Vos, P., Hogers, R., Bleeker, M., Reijans, M., van der Lee, T., Hornes, M., Frijters, A., Pot, J., Peleman, J. \& Kuiper, M. 1995: AFLP: a new technique for DNA fingerprinting. - Nucleic Acid Research 23: 4407-4414.

Wake, D. B., Roth, G. \& Wake, M. H. 1983: On the problem of stasis in organismal evolution. - Journal of Theoretical Biology 101: 211-224.

Wang, Y. Q., Wang, X. G., Xu, L. X. \& Zhang, Z. B. 2001: A new rapid method for extraction of high quality of genomic DNA from animal tissues. - Chinese Journal of Zoology 36: 27-29.

Yeh, F. C., Uang, R. C., Boyle, T. B. J., Ye, Z. H. \& Mao, J. X. 1997: POPGENE, the User-Friendly shareware for population genetic analysis. - Molecular Biology and Biotechnology Centre, University of Alberta, Cananda. 